\title{
lodide Accelerates the Processing of Biogenic Monoterpene Emissions on Marine Aerosols
}

\author{
Shinichi Enami, ${ }^{\dagger}$ Michael R. Hoffmann, ${ }^{\ddagger}$ and Agustín J. Colussi ${ }^{*}+\odot$ \\ ${ }^{\dagger}$ National Institute for Environmental Studies, 16-2 Onogawa, Tsukuba 305-8506, Japan \\ ${ }^{\ddagger}$ Linde Center for Global Environmental Science, California Institute of Technology, Pasadena, California 91125, United States
}

Supporting Information

ABSTRACT: Marine photosynthetic organisms emit organic gases, including the polyolefins isoprene $\left(\mathrm{C}_{5} \mathrm{H}_{8}\right)$ and monoterpenes (MTPs, $\left.\mathrm{C}_{10} \mathrm{H}_{16}\right)$, into the boundary layer. Their atmospheric processing produces particles that influence cloud formation and growth and, as a result, the Earth's radiation balance. Here, we report that the heterogeneous ozonolysis of dissolved $\alpha$-pinene by $\mathrm{O}_{3}(\mathrm{~g})$ on aqueous surfaces is dramatically accelerated by $\mathrm{I}^{-}$, an anion enriched in the ocean upper microlayer and sea spray aerosols (SSAs). In our experiments, liquid microjets of $\alpha$-pinene solutions, with and without added $\mathrm{I}^{-}$, are dosed with $\mathrm{O}_{3}(\mathrm{~g})$ for $\tau<10 \mu$ s and analyzed online by pneumatic ionization mass spectrometry. In the absence of $\mathrm{I}^{-}, \alpha$-pinene does not detectably react with $\mathrm{O}_{3}(\mathrm{~g})$ under present conditions. In the presence of $\geq 0.01 \mathrm{mM} \mathrm{I}^{-}$, in contrast, new signals appear at $m / z=169\left(\mathrm{C}_{9} \mathrm{H}_{13} \mathrm{O}_{3}{ }^{-}\right), m / z=183\left(\mathrm{C}_{10} \mathrm{H}_{15} \mathrm{O}_{3}{ }^{-}\right), m / z$ $=199\left(\mathrm{C}_{10} \mathrm{H}_{15} \mathrm{O}_{4}^{-}\right), m / z=311\left(\mathrm{C}_{10} \mathrm{H}_{16} \mathrm{IO}_{3}{ }^{-}\right)$, and $m / z=461\left(\mathrm{C}_{20} \mathrm{H}_{30} \mathrm{IO}_{4}{ }^{-}\right)$, plus $m / z=$ $175\left(\mathrm{IO}_{3}{ }^{-}\right)$, and $m / z=381\left(\mathrm{I}_{3}^{-}\right)$. Collisional fragmentation splits $\mathrm{CO}_{2}$ from $\mathrm{C}_{9} \mathrm{H}_{13} \mathrm{O}_{3}{ }^{-}$, $\mathrm{C}_{10} \mathrm{H}_{15} \mathrm{O}_{3}{ }^{-}$and $\mathrm{C}_{10} \mathrm{H}_{15} \mathrm{O}_{4}{ }^{-}$, and $\mathrm{I}^{-}$plus $\mathrm{IO}^{-}$from $\mathrm{C}_{10} \mathrm{H}_{16} \mathrm{IO}_{3}{ }^{-}$as expected from a trioxide $\mathrm{IOOO}^{\bullet} \mathrm{C}_{10} \mathrm{H}_{16}{ }^{-}$structure. We infer that the oxidative processing of $\alpha$-pinene on aqueous surfaces is significantly accelerated by $\mathrm{I}^{-}$via the formation of $\mathrm{IOOO}^{-}$intermediates that are more reactive than $\mathrm{O}_{3}$. A mechanism in which $\mathrm{IOOO}^{-}$reacts with $\alpha$ pinene (and likely with other unsaturated species) in competition with its isomerization to $\mathrm{IO}_{3}{ }^{-}$accounts for present results and the fact that soluble iodine in SSA is mostly present as iodine-containing organic species rather than the thermodynamically more stable iodate. By this process, a significant fraction of biogenic MTPs and other unsaturated gases may be converted to water-soluble species rather than emitted to the atmosphere.

\section{INTRODUCTION}

Particle production by bursting bubbles at the air-sea interface is the dominant global source of aerosols and a major global source of aerosol number. ${ }^{1}$ The incessant production of marine aerosols across the ocean contributes to the light-scattering properties of the marine boundary layer. ${ }^{1}$ A key feature is that both marine aerosols and the uppermost microlayers of the ocean are naturally enriched in amphiphilic and hydrophobic organic matter relative to bulk seawater. ${ }^{2-5}$ Organic matter in the open ocean is produced by photosynthetic organisms that generate volatile organic compounds (VOCs), such as dimethyl sulfide $\left(\mathrm{CH}_{3} \mathrm{SCH}_{3}\right)$, isoprene $\left(\mathrm{C}_{5} \mathrm{H}_{8}\right)$, and monoterpenes (MTPs, $\left.\mathrm{C}_{10} \mathrm{H}_{16}\right)$, ${ }^{3,6-12}$ among other species. ${ }^{13}$ The atmospheric oxidation of VOCs is deemed to generate airborne particles affecting cloud formation and growth. At present, however, large uncertainties remain regarding the strengths of marine VOCs sources, their dependence on environmental variables, such as temperature, salinity, and insolation, and the mechanisms of their chemical transformations. ${ }^{12,14}$

Isoprene and MTPs terrestrial emissions are mainly processed in the gas phase by ozone and OH-radicals. ${ }^{15}$ The marine environment is qualitatively different. The large surface area density (surface area per unit volume of air) of sea spray aerosol (SSA) particles in the marine boundary layer enhances the role of heterogeneous versus gas-phase processes. ${ }^{2}$ Significantly, the coarse $(0.1-10 \mu \mathrm{m})$ SSA particles produced from the bursting of air bubbles at the sea surface ${ }^{16,17}$ reflect the composition of interfacial microlayers. ${ }^{17,18}$ Interfacial microlayers are not only enriched in surfactants but are preferentially populated by anions, as attested by the negative polarity of the ocean's surface. ${ }^{19-22}$ Iodide, the largest halide, is enriched up to $10^{3}$ times in SSA droplets relative to bulk seawater. $^{23-25}$

Other phenomena cooperate to enhancing interfacial chemistry on SSA. Hydrophobic VOCs tend to populate the water-deficient interfacial layers rather than dissolving in bulk water. The consequence is that their concentrations at interfacial layers may exceed those calculated from Henry's law constants for gas-bulk water equilibria. ${ }^{26-28}$ Furthermore, most interfacial gas-liquid reactions are usually faster than those estimated from kinetic parameters in bulk water. ${ }^{29-35}$

Ozone is a thermodynamically strong but kinetically sluggish two-electron oxidizer. ${ }^{36}$ For example, $\mathrm{O}_{3}$ reacts with $\mathrm{Br}^{-}$and

Received: January 3, 2019

Accepted: April 15, 2019

Published: April 25, 2019 
$\mathrm{Cl}^{-}$in bulk water with relatively small rate constants $k_{\text {bromide+O }}$ $\approx 1 \times 10^{2} \mathrm{M}^{-1} \mathrm{~s}^{-1}, k_{\text {chloride }+\mathrm{O}_{3}} \approx 1 \times 10^{-2} \mathrm{M}^{-1} \mathrm{~s}^{-1}$, whereas, in marked contrast, it reacts with $\mathrm{I}^{-}$at diffusion-controlled rates $\left(k_{\text {iodide+O }} \approx 1 \times 10^{9} \mathrm{M}^{-1} \mathrm{~s}^{-1}\right){ }^{37}$ The reason is that the spinforbiddenness of the exothermic channels leading to groundstate ${ }^{3} \mathrm{O}_{2}\left(\mathrm{X}^{-}+\mathrm{O}_{3} \rightarrow \mathrm{XO}^{-}+{ }^{1,3} \mathrm{O}_{2} ; \mathrm{X}=\mathrm{Cl}^{-}, \mathrm{Br}^{-}\right.$or $\left.\mathrm{I}^{-}\right)$is selectively lifted by $\mathrm{I}^{-}$due to a heavy-atom effect. ${ }^{31}$ As a result, given the huge $\mathrm{I}^{-}$enrichment in SSA droplets and the fact that $\mathrm{I}^{-}$reacts with $\mathrm{O}_{3}$ at diffusion-controlled rates, $\mathrm{O}_{3}(\mathrm{~g})$ molecules colliding with SSA droplets are expected to largely react with $\mathrm{I}^{-}$. The final products of the $\left(\mathrm{I}^{-}+\mathrm{O}_{3}\right)$ reaction are iodate $\mathrm{IO}_{3}{ }^{-}$ and triiodide $\mathrm{I}_{3}{ }^{-38-40}$ The mechanism of reaction, inferred from measured $\mathrm{IO}_{3}{ }^{-} / \mathrm{I}_{3}{ }^{-}$ratios as functions of $\left[\mathrm{I}^{-}\right]$and $\left[\mathrm{O}_{3}\right]$, suggests the initial formation of an $\mathrm{IOOO}^{-}$intermediate (Scheme 1). ${ }^{31,37} \mathrm{IOOO}^{-}$is deemed to be the species that

\section{Scheme 1. Mechanism of Reaction ${ }^{a}$}

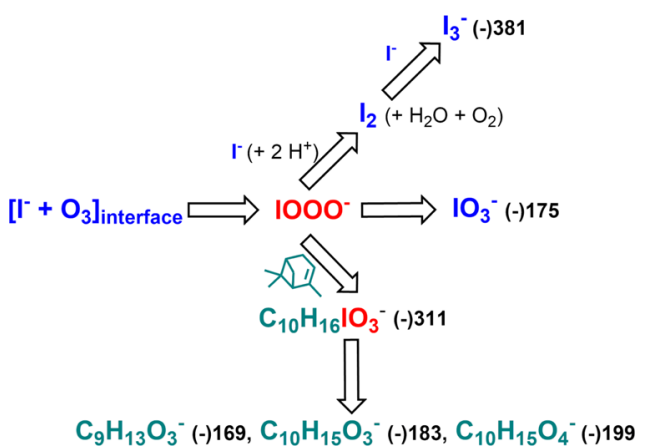

${ }^{a}$ Carboxylates (-)169, (-)183 and (-)199 could also be formed directly from $\mathrm{IOOO}^{-}$and alpha-pinene, bypassing the (-)311 intermediate.

mediates the oxidation of $\mathrm{Cl}^{-}$and $\mathrm{Br}^{-}$into gas-phase halogens over the oceans. ${ }^{31}$ It is related to the interfacial $\mathrm{Br}-\mathrm{OOO}^{-}$ intermediate recently identified by X-ray photoelectron spectroscopy. $^{41}$

The preceding considerations suggest that heterogeneous iodine chemistry on SSA droplets could play an important role in the marine boundary layers. ${ }^{42}$ Could the $\mathrm{IOOO}^{-}$ intermediates react faster than $\mathrm{O}_{3}$ with the biogenic marine MTPs emerging to the surface of the ocean? ${ }^{42-44}$ This phenomenon would enhance the oxidation of MTPs in the condensed phase prior to their release into the atmosphere. It would also explain why most soluble iodide in SSA is present as nonbiogenic iodine-containing species rather than the thermodynamically more stable iodate $\mathrm{IO}_{3}{ }^{-25,45-52}$ Here, we address these issues and report on the oxidation of $\alpha$-pinene by $\mathrm{O}_{3}(\mathrm{~g})$ in an aqueous organic solvent mixture, in the presence and absence of $\mathrm{I}^{-}$.

\section{EXPERIMENTAL SECTION}

In our experiments, $\alpha$-pinene (Sigma-Aldrich, $>98 \%$ pure, used as received) solutions in water/acetonitrile mixtures or methanol, with or without added NaI, are injected (at $50 \mu \mathrm{L}$ $\min ^{-1}$ ) as liquid microjets (at a linear velocity $v=11 \mathrm{~cm} \mathrm{~s}^{-1}$ ) into the reaction chamber of an pneumatic ionization mass spectrometer (PI-MS, Agilent 1100 MSD series, modified with an orthogonal inlet port for gas reactants) through an electrically grounded stainless-steel syringe needle $(100 \mu \mathrm{m}$ bore). The functionality of products was characterized by tandem mass spectrometry (MS/MS). The spraying chamber is flushed with $\mathrm{N}_{2}(\mathrm{~g})$ and maintained at $1 \mathrm{~atm}, 298 \mathrm{~K}$. The liquid microjets are fragmented (within $\tau_{\mathrm{R}}<10 \mu \mathrm{s}$ ) into charged microdroplets by a high velocity $\left(\sim 250 \mathrm{~m} \mathrm{~s}^{-1}\right)$ nebulizer gas $\left[\mathrm{N}_{2}(\mathrm{~g})\right]$ flowing through a sheath coaxial with the syringe needle. In these events, the kinetic energy (KE) of the nebulizing gas provides energy for creating the surfaces of the microdroplets and for charging the microdroplets by separating the anions and cations already present in the microjets. Nebulization is the single event that generates the net charges detected as mass spectral signals. This charging process does not require but may be enhanced by the presence of an electric field. We have shown that in our setup the creation of net charge is mainly due to pneumatic nebulization rather than due to the applied electric field needed to deflect the charged microdroplets toward the mass analyzer. ${ }^{29,53}$ Reactive events take place upon exposing the liquid microjets to $\mathrm{O}_{3}(\mathrm{~g})$ during their $\tau<10 \mu \mathrm{s}$ lifetimes prior to nebulization. Reaction products are detected online without manipulation by PI-MS in less than $1 \mathrm{~ms}$. We have shown that the detected ions originate from species produced in the outermost interfacial layers of intact liquid microjets, rather than on the microdroplets produced by nebulization, or in gas-phase reactions. Further experimental details may be found in previous publications. $^{29,32,54,55}$

Ozone was generated by flowing ultrapure $\mathrm{O}_{2}(\mathrm{~g})$ (>99.998\%) through a silent discharge ozonizer and quantified via online UV-vis absorption spectrophotometry (HP 8452) before entering the reaction chamber. Reported $\left[\mathrm{O}_{3}(\mathrm{~g})\right]$ values correspond to concentrations on the surface of the liquid microjets, which we estimated by multiplying the concentrations determined by absorption spectrophotometry by a $\sim 1 / 10$ factor due to dilution by the nebulizing gas flow. Conditions in these experiments were drying nitrogen gas flow rate: $10 \mathrm{~L} \mathrm{~min}^{-1}$; drying nitrogen gas temperature: $340{ }^{\circ} \mathrm{C}$; and capillary inlet voltage: $+3.5 \mathrm{kV}$ relative to the grounded injector.

\section{RESULTS AND DISCUSSION}

The negative ion mass spectrum obtained in experiments involving microjets of $6.4 \mathrm{mM} \alpha$-pinene solutions in water/ acetonitrile mixtures $(1: 4 / \mathrm{v} / \mathrm{v})$ exposed to $630 \mathrm{ppmv} \mathrm{O}_{3}(\mathrm{~g})$ for $\tau_{\mathrm{R}}<10 \mu \mathrm{s}$ is shown as a black trace in Figure 1 . Note that signals are within the background noise level. Reactant concentrations were chosen to produce detectable products during the short $\tau_{\mathrm{R}}<10 \mu \mathrm{s}$ contact times. It should be emphasized that in our experiments, ozone exposures $E=$ $\left[\mathrm{O}_{3}(\mathrm{~g})\right] \times \tau_{\mathrm{R}} \leq 630 \mathrm{ppmv} \times 10 \mu \mathrm{s}=6.3 \mathrm{ppbv}$ s are much smaller than typical exposures to $20 \mathrm{ppb} \mathrm{O}_{3}(\mathrm{~g})$ (see below) for $1 \mathrm{~h}: 20 \mathrm{ppbv} \times 3600 \mathrm{~s}=7.2 \times 10^{4} \mathrm{ppbv} \mathrm{s}$, in remote marine boundary layers. As a reference, the half-life of gas-phase $\alpha$ pinene toward $\mathrm{O}_{3}$ in the troposphere is $\sim 4 \mathrm{~h} .{ }^{44}$ By analogy with reported rate constants for the (1-hexene-4-ol $+\mathrm{O}_{3}$ ) reaction in water ${ }^{56}$ and in the gas phase, ${ }^{57}$ we assume that the rate constant of the $\left(\alpha\right.$-pinene $\left.+\mathrm{O}_{3}\right)$ reaction in bulk water is within a factor of two of its value in the gas phase: $k_{\text {bulk water }}(\alpha$ pinene $\left.+\mathrm{O}_{3}\right)=8.7 \times 10^{-17} \mathrm{~cm}^{3}$ molecule ${ }^{-1} \mathrm{~s}^{-1}=5.2 \times 10^{4}$ $\mathrm{M}^{-1} \mathrm{~s}^{-1}$. Therefore, the largest possible value of the pseudo first-order rate constant for $\alpha$-pinene decay in bulk water in equilibrium with $630 \mathrm{ppmv} \mathrm{O}_{3}(\mathrm{~g})$, that is, $\left[\mathrm{O}_{3}\right]_{\mathrm{aq}}=6.3 \mu \mathrm{M}$, (from Henry's law constant for $\mathrm{O}_{3}$ in water at $298 \mathrm{~K}: \mathrm{H}=0.01$ $\mathrm{M}$ atm $\left.{ }^{-1}\right)^{58}$ would be ${ }^{1} k=\left(5.2 \times 10^{4} \mathrm{M}^{-1} \mathrm{~s}^{-1}\right) \times 6.3 \mu \mathrm{M}=0.3$ $\mathrm{s}^{-1}$. In consequence, the shortest predicted half-life of $\alpha$-pinene 


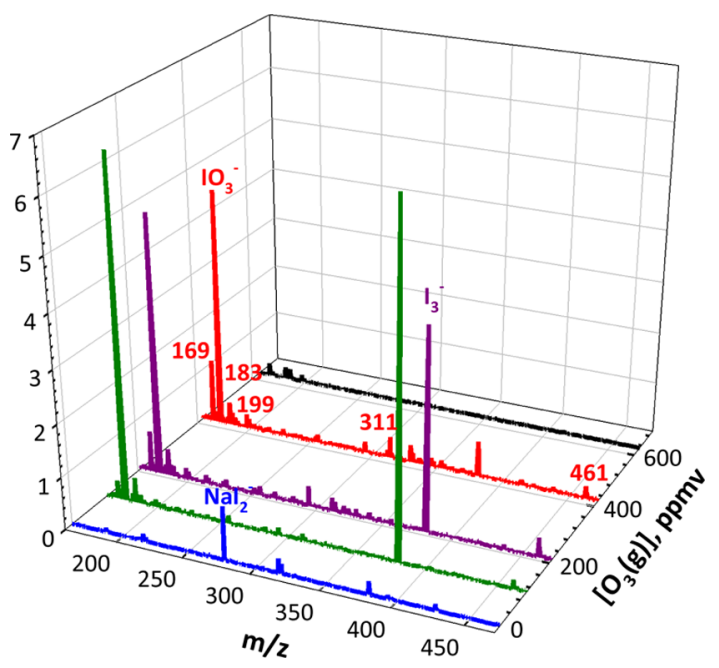

Figure 1. Colored traces are mass spectral signal intensities (vertical axis, in arbitrary units) of the anions produced on the surface of microjets of $(6.4 \mathrm{mM} \alpha$-pinene $+0.1 \mathrm{mM} \mathrm{NaI})$ solutions in water/ acetonitrile/1:4 $(\mathrm{v} / \mathrm{v})$ exposed to different $\mathrm{O}_{3}(\mathrm{~g})$ concentrations for $<10 \mu$ s. Signals correspond to $m / z=169\left(\mathrm{C}_{9} \mathrm{H}_{13} \mathrm{O}_{3}{ }^{-}\right), m / z=183$ $\left(\mathrm{C}_{10} \mathrm{H}_{15} \mathrm{O}_{3}^{-}\right), m / z=199\left(\mathrm{C}_{10} \mathrm{H}_{15} \mathrm{O}_{4}^{-}\right), m / z=311\left(\mathrm{C}_{10} \mathrm{H}_{16} \mathrm{IO}_{3}^{-}\right)$, and $m / z=461\left(\mathrm{C}_{20} \mathrm{H}_{30} \mathrm{IO}_{4}^{-}\right)$, plus $m / z=175\left(\mathrm{IO}_{3}^{-}\right)$and $m / z=381$ $\left(\mathrm{I}_{3}{ }^{-}\right)$species. Note the small amounts of $\mathrm{I}_{3}^{-}$present (from $\mathrm{I}^{-}$ autoxidation in the injected iodide solutions) in the absence of $\mathrm{O}_{3}(\mathrm{~g})$ (blue trace).The black trace corresponds to mass spectral signal intensities from of $6.4 \mathrm{mM} \alpha$-pinene solutions in water/acetonitrile/ $1: 4(\mathrm{v} / \mathrm{v})$ (i.e., in the absence of iodide) exposed to $630 \mathrm{ppmv} \mathrm{O}_{3}(\mathrm{~g})$ for $<10 \mu$ s. Note the low intensity of $m / z=169\left(\mathrm{C}_{9} \mathrm{H}_{13} \mathrm{O}_{3}{ }^{-}\right), \mathrm{m} / z=$ $183\left(\mathrm{C}_{10} \mathrm{H}_{15} \mathrm{O}_{3}^{-}\right)$, and $m / z=199\left(\mathrm{C}_{10} \mathrm{H}_{15} \mathrm{O}_{4}{ }^{-}\right)$signals in the absence of $\mathrm{NaI}$, which are due to $\alpha$-pinene impurities.

in experiments performed under such conditions would be a few seconds, which is $\sim 6$ orders of magnitude longer than the $\tau_{\mathrm{R}}<10 \mu \mathrm{s}$ time window of our experiments. However, as another example that most interfacial reactions run faster than anticipated from kinetic data in bulk water, we have found that dissolved $\alpha$-pinene does react with $\mathrm{O}_{3}(\mathrm{~g})$ to produce small amounts of the neutral $\alpha$-hydroxy hydroperoxides (detected as chloride adducts in the presence of added $\mathrm{NaCl}$ ) expected from the addition of water to the putative Criegee intermediates. $^{59}$

We obtained very different results in the presence of $\mathrm{NaI}$. The blue trace in Figure 1 corresponds to a mass spectrum obtained from $0.1 \mathrm{mM} \mathrm{NaI}$ solutions in a water/acetonitrile $(1: 4 / \mathrm{v} / \mathrm{v})$ in the absence of $\mathrm{O}_{3}$. The dominant peak at $\mathrm{m} / z=$ 277 corresponds to a $\mathrm{NaI}_{2}{ }^{-}$cluster ion. We verified that acetonitrile is inert toward $\mathrm{O}_{3}(\mathrm{~g})$ in our experiments, in the presence or absence of $\mathrm{I}^{-60,61}$ Experiments performed by exposing (6.4 $\mathrm{mM} \alpha$-pinene $+0.1 \mathrm{mM} \mathrm{NaI})$ solutions in water/acetonitrile $(1: 4 / \mathrm{v} / \mathrm{v})$ to $\mathrm{O}_{3}(\mathrm{~g})$ in the reactor chamber of the mass spectrometer led to the mass spectra shown as green, dark pink, and red traces in Figure 1. New, major mass spectral signals appear at $m / z=169\left(\mathrm{C}_{9} \mathrm{H}_{13} \mathrm{O}_{3}{ }^{-}\right), m / z=183$ $\left(\mathrm{C}_{10} \mathrm{H}_{15} \mathrm{O}_{3}^{-}\right), m / z=199\left(\mathrm{C}_{10} \mathrm{H}_{15} \mathrm{O}_{4}^{-}\right), m / z=311$ $\left(\mathrm{C}_{10} \mathrm{H}_{16} \mathrm{IOOO}^{-}\right)$, and $m / z=461\left(\mathrm{C}_{20} \mathrm{H}_{30} \mathrm{IO}_{4}{ }^{-}\right)$, plus $m / z=$ $175\left(\mathrm{IO}_{3}{ }^{-}\right)$, and $m / z=381\left(\mathrm{I}_{3}^{-}\right)$. The same products were also observed from $(5 \mathrm{mM} \alpha$-pinene $+0.1 \mathrm{mM} \mathrm{NaI})$ solutions in methanol (Figure S1). Additional experiments showed that $\mathrm{C}_{10} \mathrm{H}_{16} \mathrm{IO}_{3}^{-}$is the product of the addition of an $\mathrm{IOOO}^{-}$ trioxide intermediate to $\alpha$-pinene rather than an $\alpha$-pinene- $\mathrm{IO}_{3}{ }^{-}$ adduct (see below). These experiments imply that $\mathrm{O}_{3}(\mathrm{~g})$ oxidizes $\mathrm{I}^{-}$to produce intermediates that react with $\alpha$-pinene much faster than $\mathrm{O}_{3}(\mathrm{~g})$. We had previously found that these intermediates, likely $\mathrm{IOOO}^{-}$(and, possibly $\mathrm{HOI}$ ), are also very reactive toward other species, such as halide anions and sulfite. $^{31,32} \mathrm{We}{ }^{54,60,62}$ and others, ${ }^{33-35,63}$ have found that heterogeneous reactions on the surfaces of liquids are significantly faster than those in the bulk phases.

Figure 2 reports the dependence of mass signal intensities on fragmentor voltage $(\mathrm{FV}) . \mathrm{FV}$ is the electrical potential

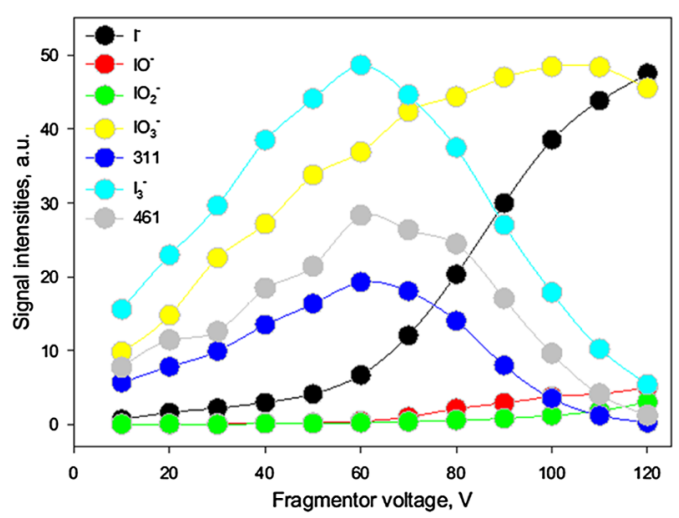

Figure 2. Mass spectral signal intensities versus FV of the anions produced on the surface of microjets of $(\alpha$-pinene $+\mathrm{NaI})$ solutions in acetonitrile exposed to $300 \mathrm{ppmv}_{3}(\mathrm{~g})$ for $<10 \mu \mathrm{s}$.

difference between the exit of the heated capillary and first skimmer of the mass spectrometer. ${ }^{29}$ In this region, ions are accelerated up to excess laboratory KEs given by $\mathrm{KE}=\mathrm{FV} \times z_{i} e$ $=1 / 2 m_{i} v_{i}^{2}$, where $z_{i} e$ is the charge, $m_{i}$ is the mass, and $v_{i}$ is the excess velocity of ion $i$. Molecular ions convert their excess $\mathrm{KE}$ into internal (vibrational and rotational) excitation during impact with the $\mathrm{N}_{2}$ bath gas molecules. $\mathrm{KE}$ are converted to center-of-mass (CEM) KEs by the following relationship: $\mathrm{CEM}=m /\left(m+m_{i}\right) \mathrm{KE}$, where $m=28$ is the molecular mass of the $\mathrm{N}_{2}$ collider gas. ${ }^{30}$ The CEM onsets of fragmentation, in volts, for the different species are collected in Table 1 . These experiments reveal that $(-) 183$ and $(-) 199$ are carboxylates, which we assume are the anions of pinonic and hydroxypinonic acids, which split $\mathrm{CO}_{2}$ upon fragmentation. ${ }^{64}$ The (-) 169 signal which splits $\mathrm{CO}_{2}$ may correspond to the anion of pinalic acid. These assignments are based on literature reports ${ }^{65}$ because molecular structures cannot be deduced solely from the molecular formulas provided by mass spectrometry. The $(-) 311$ anion both splits $(-) 143\left(\mathrm{IO}^{-}\right)$and $(-) 127\left(\mathrm{I}^{-}\right)$, as expected from a species containing a $\mathrm{IO}^{-}$functionality. We confirmed that the $(-) 143$ anion is $\mathrm{IO}^{-}$because it splits $\mathrm{I}^{-}$. Distinctively, (-)461 fragments into $\mathrm{I}^{-}$and (-)311 at a threshold voltage significantly lower than for the other species. This finding suggests a weakly bound species which formally corresponds to the association of partially oxidized $\alpha$-pinene $\mathrm{C}_{10} \mathrm{H}_{16} \mathrm{O}_{2}\left(136+\mathrm{O}_{2}\right)$ with $(-) 311$, followed by a $\mathrm{H}_{2} \mathrm{O}$ loss: $461=(136+32)+(136+127+48)-18$.

The dependences of the inorganic products of $\mathrm{I}^{-}$oxidation, iodate $\mathrm{IO}_{3}{ }^{-}$, and triiodide $\mathrm{I}_{3}^{-}$(Figure $3 \mathrm{~A}$ ) and those derived from the reaction of $\alpha$-pinene with $\mathrm{IOOO}^{-}$(Figure 3B,C) as functions of $[\mathrm{NaI}]$ and $[\alpha$-pinene $]$ (Figure 4) are consistent with the mechanism of Scheme 1. In Figure 3D, the negligible intensity of the $m / z=311$ mass signal in the presence of added $\mathrm{IO}_{3}{ }^{-}$in the absence of $\mathrm{O}_{3}$ (i.e., at $\left[\mathrm{O}_{3}\right]=0$ ), in conjunction with its fragmentation into $(-) 143\left(\mathrm{IO}^{-}\right)$and $(-) 127\left(\mathrm{I}^{-}\right)$ 
Table 1. Threshold CEM Energies (in Volts) of the Fragmentation of the Anions Produced from ( $\alpha$-Pinene + Sodium Iodide) Solutions Exposed to $\mathrm{O}_{3}(\mathrm{~g})$ (See Main Text)

\begin{tabular}{lc}
\multicolumn{1}{c}{ anion $(\mathrm{Da})$} & threshold voltage $(\mathrm{V})$ \\
$169\left(\mathrm{C}_{9} \mathrm{H}_{13} \mathrm{O}_{3}^{-}\right)$ & $1.4 \pm 0.1$ \\
$183\left(\mathrm{C}_{10} \mathrm{H}_{15} \mathrm{O}_{3}^{-}\right)$ & $1.4 \pm 0.1$ \\
$199\left(\mathrm{C}_{10} \mathrm{H}_{15} \mathrm{O}_{4}^{-}\right)$ & $1.4 \pm 0.1$ \\
$311\left(\mathrm{C}_{10} \mathrm{H}_{16} \mathrm{IO}_{3}^{-}\right)$ & $1.3 \pm 0.1$ \\
$143\left(\mathrm{IO}^{-}\right)$ & $1.6 \pm 0.1$ \\
$461\left(\mathrm{C}_{20} \mathrm{H}_{30} \mathrm{IO}_{4}^{-}\right)$ & $0.3 \pm 0.1$
\end{tabular}

(see above), strongly suggests that this species is a covalent trioxide $\mathrm{IOOOC}_{10} \mathrm{H}_{16}{ }^{-}$rather than a $\mathrm{C}_{10} \mathrm{H}_{16}-\mathrm{IO}_{3}{ }^{-}$adduct. Furthermore, the competition between $\alpha$-pinene and $\mathrm{I}^{-}$for the putative trioxide $\mathrm{IOOO}^{-}$accounts for the direct and inverse dependences of the signal intensities of the inorganic species $\mathrm{IO}_{3}{ }^{-}$and $\mathrm{I}_{3}{ }^{-}$versus those of the $(-) 311,(-) 168,(-) 183$, and $(-) 199$ organic species, as functions of the $\left[\mathrm{I}^{-}\right] /[\alpha$-pinene $]$ ratio. As mentioned above, because the formation of the (-)461 species requires relatively larger concentrations of $\alpha$ pinene (Figure 4), it may not be relevant to the chemistry of SSA droplets in the marine boundary layer. It is apparent that the formation of $\mathrm{IO}_{3}{ }^{-}$and $\mathrm{I}_{3}{ }^{-}$, and also of $\mathrm{I}_{2}$, will be quenched by unsaturated species such as MTPs and other unsaturated species, such as the polyunsaturated fatty acids ${ }^{66}$ present on the surface of oceans over active phytoplankton populations. The iodine-containing organic species $\mathrm{m} / \mathrm{z}=311$ $\left(\mathrm{C}_{10} \mathrm{H}_{16} \mathrm{IO}_{3}{ }^{-}\right)$and $m / z=461\left(\mathrm{C}_{20} \mathrm{H}_{30} \mathrm{IO}_{4}{ }^{-}\right)$are considered representatives of the class of unidentified soluble organic iodine (UOIs) species detected in SSA particles. ${ }^{45,46}$ Our results provide a chemical, as opposed to a biological mechanism for the incorporation of iodide into UOIs, which account for up to $50 \%$ of total soluble iodine (TSI) and up to $70 \%$ of soluble organic iodine (SOI) in SSA. ${ }^{45,46,67}$

How fast could these interfacial processes be under realistic marine boundary conditions? We base our estimates on the total integral properties (in the $0.1-30 \mu \mathrm{m}$ particle radius range) of SSA populations in the boundary layer at $80 \%$ relative humidity under a mean wind speed of $u=10 \mathrm{~m} \mathrm{~s}^{-1}$ at $10 \mathrm{~m}$ above the sea surface. ${ }^{4}$ From Table 15, p 174 of ref 4, we assume SSA populations of specific surface area (SSA integral area per $\mathrm{cm}^{-3}$ of air at $80 \%$ relative humidity): $A_{80} \approx 300 \mu \mathrm{m}^{2}$ $\mathrm{cm}^{-3}=3 \times 10^{-6} \mathrm{~cm}^{2} \mathrm{~cm}^{-3}$ and specific volume: $V_{80} \approx 500 \mu \mathrm{m}^{3}$ $\mathrm{cm}^{-3}=5 \times 10^{-10} \mathrm{~cm}^{3} \mathrm{~cm}^{-3}$. We assume typical $20 \mathrm{ppbv} \mathrm{O}_{3}(\mathrm{~g})$ $=5 \times 10^{11}$ molecules $\mathrm{cm}^{-3}$ (at 1 atm, $300 \mathrm{~K}$ ), daytime concentrations over the ocean. ${ }^{68} \mathrm{We}$ also assume a representative median concentration of TSI in aerosols of $[\mathrm{TSI}] \approx 200 \mathrm{pmol} \mathrm{m}^{-3}=1.2 \times 10^{8}$ iodine atoms cm $\mathrm{cm}^{-3}$ (in SSA particles collected in all impactor stages), which is mostly associated with the SOI fraction. ${ }^{25,48}$ We verified that this figure is in the range reported by independent studies. ${ }^{69}$ Therefore, the actual concentration of iodine in SSA particles is [iodine $]_{\mathrm{SSA}}=[\mathrm{TSI}] / V_{80}=2.4 \times 10^{17} \mathrm{I}$ atoms $\mathrm{cm}^{-3}=0.4$ $\mathrm{mM}$. It should be emphasized that the actual concentration of free, oxidizable $\mathrm{I}^{-}$may be a fraction of that figure. Note that the mean concentration of iodide at the sea surface is $\left[\mathrm{I}^{-}\right]_{\text {sea surface }} \approx 0.250 \mu \mathrm{M},{ }^{24}$ that is, about 3 orders of magnitude smaller than [iodine $]_{\text {SSA }}$.

By assuming that the diffusive gas-phase resistance to microsized SSA particles can be neglected as a first approximation, ${ }^{70}$ the flux of $\mathrm{O}_{3}(\mathrm{~g})$ molecules, $F_{\mathrm{O}_{3}}$, that would react with dissolved $\mathrm{I}^{-}$to produce $\mathrm{IOOO}^{-}$can be estimated from the kinetic theory of gases: ${ }^{70,71} F_{\mathrm{O}_{3}}=1$ /

\begin{tabular}{ll}
\multicolumn{1}{c}{ fragment anion $(\mathrm{Da})$} & \multicolumn{1}{c}{ neutral loss $(\mathrm{Da})$} \\
$125\left(\mathrm{C}_{8} \mathrm{H}_{13} \mathrm{O}^{-}\right)$ & $44\left(\mathrm{CO}_{2}\right)$ \\
$139\left(\mathrm{C}_{9} \mathrm{H}_{15} \mathrm{O}^{-}\right)$ & $44\left(\mathrm{CO}_{2}\right)$ \\
$155\left(\mathrm{C}_{9} \mathrm{H}_{15} \mathrm{O}_{2}^{-}\right)$ & $44\left(\mathrm{CO}_{2}\right)$ \\
$143\left(\mathrm{IO}^{-}\right), 127\left(\mathrm{I}^{-}\right)$ & $168\left(\mathrm{C}_{10} \mathrm{H}_{16} \mathrm{O}_{2}\right), 184\left(\mathrm{C}_{10} \mathrm{H}_{16} \mathrm{O}_{3}\right)$ \\
$127\left(\mathrm{I}^{-}\right)$ & $16(\mathrm{O})$ \\
$127 / 311\left(\mathrm{I}^{-} / \mathrm{C}_{10} \mathrm{H}_{16} \mathrm{IO}_{3}^{-}\right)$ & $334 / 150\left(\mathrm{C}_{20} \mathrm{H}_{30} \mathrm{O}_{4} / \mathrm{C}_{10} \mathrm{H}_{14} \mathrm{O}\right)$
\end{tabular}

$4 c_{\mathrm{O}_{3}} n_{\mathrm{O}_{3}} \gamma_{\mathrm{O}_{3}} \approx 4.5 \times 10^{15} \gamma_{\mathrm{O}_{3}}$ molecules $\mathrm{cm}^{-2} \mathrm{~s}^{-1} \cdot c_{\mathrm{O}_{3}}=3.63 \times$ $10^{4} \mathrm{~cm} \mathrm{~s}^{-1}$ is the mean thermal velocity of $\mathrm{O}_{3}$ molecules at 300 $\mathrm{K}$, and $\gamma_{\mathrm{O}_{3}}$ is the reactive uptake coefficient of $\mathrm{O}_{3}$ on SSA droplets. By adopting the $\gamma_{\mathrm{O}_{3}} \approx 10^{-4}$ value reported on aqueous $\left[\mathrm{I}^{-}\right] \approx 0.1 \mathrm{mM}$ solutions, ${ }^{39}$ we arrive at $F_{\mathrm{O}_{3}} \approx 4.5 \times$ $10^{11}$ molecules $\mathrm{cm}^{-2} \mathrm{~s}^{-1}$. The rate at which $\mathrm{SSA} \mathrm{I}^{-}$would be titrated by $\mathrm{O}_{3}$ is therefore $\mathrm{F}_{\mathrm{O}_{3}} A_{80} \approx 1.4 \times 10^{6} \mathrm{I}^{-}$ions $\mathrm{cm}^{-3} \mathrm{~s}^{-1}$. These estimates show that $\mathrm{O}_{3}(\mathrm{~g})$ will titrate half of the $\mathrm{I}^{-}$into $\mathrm{IOOO}^{-}$in air containing $[\mathrm{TSI}] \approx 1.2 \times 10^{8}$ iodine atoms $\mathrm{cm}^{-3}$ in less than a minute.

The rate of oxidation of $\mathrm{I}^{-}$by $\mathrm{O}_{3}(\mathrm{~g})$ in the outermost interfacial layers of the ocean can be estimated from an interfacial iodide concentration given by $\left[\mathrm{I}^{-}\right]_{\text {interfacial }}=0.250$ $\mu \mathrm{M} \times \delta=\left(1.5 \times 10^{14} \mathrm{I}^{-}\right.$ions $\left.\mathrm{cm}^{-3}\right) \times\left(3 \times 10^{-4} \mathrm{~cm}\right)=4.5 \times$ $10^{10} \mathrm{I}^{-}$ions $\mathrm{cm}^{-2}$, where $\delta=3 \times 10^{-4} \mathrm{~cm}$ is the reactodiffusive length of $\mathrm{O}_{3}$ in $\left[\mathrm{I}^{-}\right] \approx 0.1 \mu \mathrm{M}$ seawater. ${ }^{39}$ The critical difference between the sea surface and SSA particles is that at $\left[\mathrm{I}^{-}\right] \approx 0.1 \mu \mathrm{M}$, the reactive uptake coefficient of $\mathrm{O}_{3}(\mathrm{~g})$ is about 3 orders of magnitude smaller than on SSA particles: $\gamma_{\mathrm{O}_{3}} \approx$ $10^{-7} \cdot 39$ If the incorporation of $\mathrm{O}_{3}(\mathrm{~g})$ into seawater were exclusively controlled by its reaction with $\mathrm{I}^{-}$, we estimate that the flux of $\mathrm{O}_{3}(\mathrm{~g})$ into seawater would be $\mathrm{F}_{\mathrm{O}_{3}} \approx 4.5 \times 10^{8}$ molecules cm $\mathrm{cm}^{-2} \mathrm{~s}^{-1}$ and, therefore, that $\left[\mathrm{I}^{-}\right]_{\text {interfacial }}=4.5 \times 10^{10}$ $\mathrm{I}^{-}$ions $\mathrm{cm}^{-2}$ would be also titrated in about a minute. However, the fact that the velocity of dry deposition of $\mathrm{O}_{3}(\mathrm{~g})$ on the ocean, $v_{\mathrm{d}}$, was found to be enhanced by wind velocity $u$ reveals the importance of wind-induced turbulent gas-transfer. ${ }^{12}$ In fact, $v_{\mathrm{d}}$ increases fivefold from 0.016 to $0.078 \mathrm{~cm} \mathrm{~s}^{-1}$ as wind speed goes from $u=0$ to $20 \mathrm{~m} \mathrm{~s}^{-1}$. ${ }^{72}$ Therefore, at a mean $v_{\mathrm{d}} \approx 0.03 \mathrm{~cm} \mathrm{~s}^{-1}$ value, $\sim 1.5 \times 10^{10} \mathrm{O}_{3}$ molecules $\mathrm{cm}^{-2}$ $\mathrm{s}^{-1}$ would penetrate the surface of the ocean, that is, that $\mathrm{O}_{3}(\mathrm{~g})$ will titrate $\left[\mathrm{I}^{-}\right]_{\text {interfacial }}=4.5 \times 10^{10} \mathrm{I}^{-}$ions $\mathrm{cm}^{-2}$ in a few seconds. Note that this estimate could be a lower limit if the reaction were also partially controlled by aqueous phase resistance in the surface of water. It is apparent that the chemistry delineated by our experiments and analysis could rapidly process marine biogenic gas emissions whether at the ocean surface or on SSA. ${ }^{49,73-75}$

Summing up, we have shown that iodide at low concentrations dramatically accelerates the conversion by $\mathrm{O}_{3}$ of $\alpha$-pinene on aqueous surfaces into organic acids and Icontaining organic species. Our findings provide a plausible mechanism for the formation of the unidentified soluble iodine-containing organic anionic species detected on SSA droplets and for the low concentrations of $\mathrm{IO}_{3}{ }^{-}$therein. ${ }^{45,46}$ They also suggest that a fraction of the MTPs and other VOCs produced by marine organisms may not be emitted to the atmosphere but converted to species dissolved in seawater or SSA droplets. This process should be eventually considered and incorporated in current estimates of isoprene and MTP 

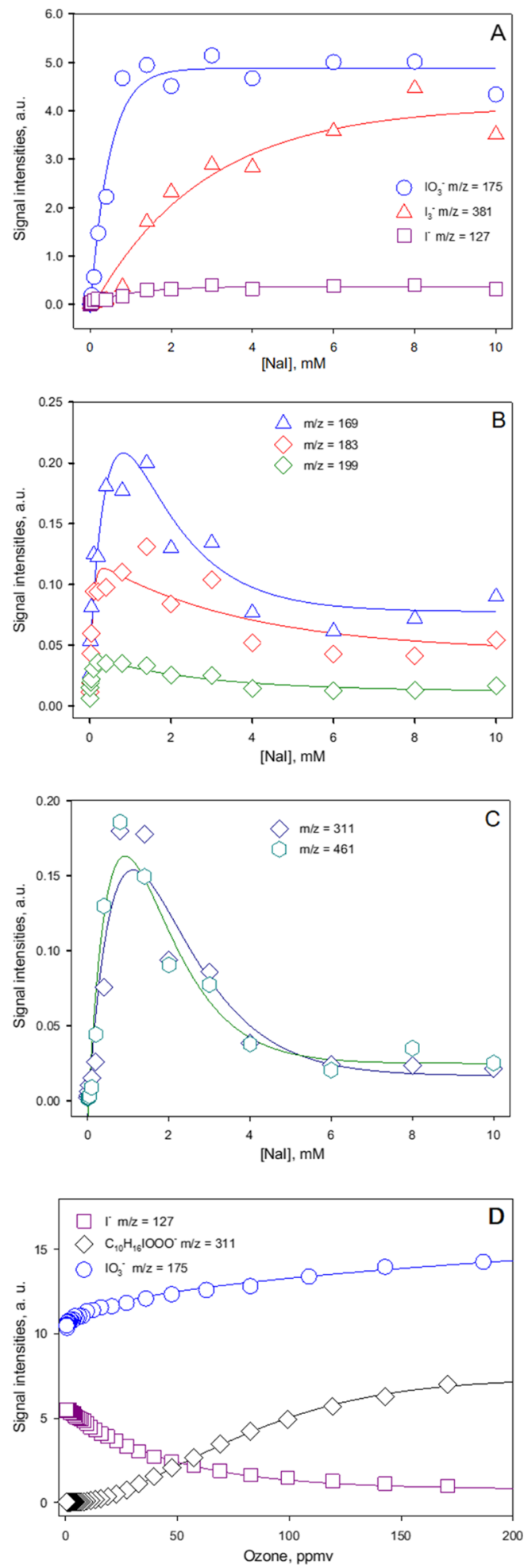

Figure 3. (A-C) Mass spectral signal intensities versus $\mathrm{NaI}$ concentration of anions produced on the surface of microjets of $(6.4 \mathrm{mM} \alpha$-pinene $+\mathrm{NaI})$ solutions in water/acetonitrile/1:4 (v/v) exposed to $730 \mathrm{ppmv}_{3}(\mathrm{~g})$ for $<10 \mu \mathrm{s}$. (D) Mass spectral signal intensities as functions of $\mathrm{O}_{3}(\mathrm{~g})$ concentration of anions produced on the surface of microjets of $(1 \mathrm{mM} \alpha$-pinene $+0.05 \mathrm{mM} \mathrm{NaI}+0.5 \mathrm{mM}$ $\left.\mathrm{NaIO}_{3}\right)$ solutions in methanol exposed to $\mathrm{O}_{3}(\mathrm{~g})$ for $<10 \mu \mathrm{s}$. The negligible intensity of the $\mathrm{m} / z=311$ mass signal in the presence of $\mathrm{IO}_{3}^{-} \mathrm{m} / z=175$ at $\left[\mathrm{O}_{3}\right]=0$ proves that it is associated with a $\mathrm{C}_{10} \mathrm{H}_{16} \mathrm{IOOO}^{-}$trioxide rather than a $\mathrm{C}_{10} \mathrm{H}_{16}-\mathrm{IO}_{3}^{-}$adduct. Connecting lines are guides to the eye.

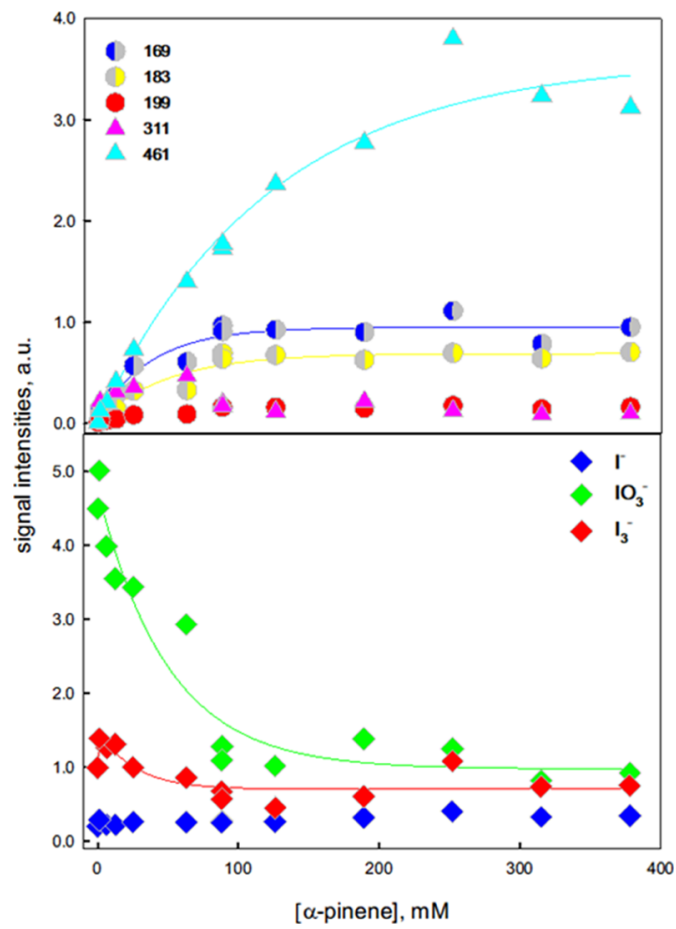

Figure 4. Mass spectral signal intensities versus $\alpha$-pinene concentration of the anions produced on the surface of microjets of $(\alpha$ pinene $+0.1 \mathrm{mM} \mathrm{NaI})$ solutions in water/acetonitrile/1:4 (v/v) exposed to $730 \mathrm{ppmv} \mathrm{O}_{3}(\mathrm{~g})$ for $<10 \mu$ s. Connecting lines are guides to the eye.

ocean fluxes based on correlations between laboratory data production rates and chlorophyll satellite sightings, as reported by a recent, authoritative review on marine isoprene and MTP emissions. $^{10,76}$

\section{ASSOCIATED CONTENT}

\section{S Supporting Information}

The Supporting Information is available free of charge on the ACS Publications website at DOI: 10.1021/acsomega.9b00024.

Mass spectrum of products in methanol solutions (PDF)

\section{AUTHOR INFORMATION}

\section{Corresponding Author}

*E-mail: ajcoluss@caltech.edu.

\section{ORCID}

Shinichi Enami: 0000-0002-2790-7361

Agustín J. Colussi: 0000-0002-3400-4101

Notes

The authors declare no competing financial interest.

\section{ACKNOWLEDGMENTS}

We thank Sayaka Hayase and Masahiro Kawasaki (Kyoto University) for their help. S.E. was supported by the Japan Society for the Promotion of Sciences Postdoctoral Fellowship for Research Abroad. M.R.H. and A.J.C. acknowledge the support from the National Science Foundation USA, grant AGS-1744353. 


\section{REFERENCES}

(1) Long, M. S.; Keene, W. C.; Kieber, D. J.; Erickson, D. J.; Maring, H. A sea-state based source function for size-and compositionresolved marine aerosol production. Atmos. Chem. Phys. 2011, 11, $1203-1216$.

(2) de Leeuw, G.; Andreas, E. L.; Anguelova, M. D.; Fairall, C. W.; Lewis, E. R.; O’Dowd, C.; Schulz, M.; Schwartz, S. E. Production flux of sea spray aerosol. Rev. Geophys. 2011, 49, RG2001.

(3) Hackenberg, S. C.; Andrews, S. J.; Airs, R. L.; Arnold, S. R.; Bouman, H. A.; Cummings, D.; Lewis, A. C.; Minaeian, J. K.; Reifel, K. M.; Small, A.; Tarran, G. A.; Tilstone, G. H.; Carpenter, L. J. Basinscale observations of monoterpenes in the Arctic and Atlantic Oceans. Environ. Sci. Technol. 2017, 51, 10449-10458.

(4) Lewis, E. R.; Schwartz, S. E. Sea Salt Aerosol Production: Mechanisms, Methods, Measurements and Models-A Critical Review; Geophysical Monograph; American Geophysical Union: Washington, DC, 2004; Vol. 152.

(5) Ciuraru, R.; Fine, L.; Pinxteren, M. v.; D’Anna, B.; Herrmann, $\mathrm{H}$; George, C. Unravelling new processes at interfaces: photochemical isoprene production at the sea surface. Environ. Sci. Technol. 2015, 49, 13199-13205.

(6) Kim, M. J.; Novak, G. A.; Zoerb, M. C.; Yang, M.; Blomquist, B. W.; Huebert, B. J.; Cappa, C. D.; Bertram, T. H. Air-sea exchange of biogenic volatile organic compounds and the impact on aerosol particle size distributions. Geophys. Res. Lett. 2017, 44, 3887-3896.

(7) Luo, G.; Yu, F. A numerical evaluation of global oceanic emissions of $\alpha$-pinene and isoprene. Atmos. Chem. Phys. 2010, 10, 2007-2015.

(8) Bouvier-Brown, N. C.; Goldstein, A. H.; Gilman, J. B.; Kuster, W. C.; de Gouw, J. A. In-situ ambient quantification of monoterpenes, sesquiterpenes, and related oxygenated compounds during BEARPEX 2007: implications for gas- and particle-phase chemistry. Atmos. Chem. Phys. 2009, 9, 5505-5518.

(9) Meskhidze, N.; Sabolis, A.; Reed, R.; Kamykowski, D. Quantifying environmental stress-induced emissions of algal isoprene and monoterpenes using laboratory measurements. Biogeosciences 2015, 12, 637-651.

(10) Shaw, S. L.; Gantt, B.; Meskhidze, N. Production and emissions of marine isoprene and monoterpenes: a review. Adv. Meteorol. 2010, 2010, 408696

(11) Yassaa, N.; Peeken, I.; Zöllner, E.; Bluhm, K.; Arnold, S.; Spracklen, D.; Williams, J. Evidence for marine production of monoterpenes. Environ. Chem. 2008, 5, 391-401.

(12) Carpenter, L. J.; Archer, S. D.; Beale, R. Ocean-atmosphere trace gas exchange. Chem. Soc. Rev. 2012, 41, 6473-6506.

(13) Fu, P.; Kawamura, K.; Miura, K. Molecular characterization of marine organic aerosols collected during a round-the-world cruise. J. Geophys. Res.: Atmos. 2011, 116, D13302.

(14) Qu, B.; Gabric, A. J.; Zhao, L.; Sun, W.; Li, H.; Gu, P.; Jiang, L.; Zeng, M. The relationships among aerosol optical depth, ice, phytoplankton and dimethylsulfide and the implication for future climate in the Greenland Sea. Acta Oceanol. Sin. 2018, 37, 13-21.

(15) Wennberg, P. O.; Bates, K. H.; Crounse, J. D.; Dodson, L. G.; McVay, R. C.; Mertens, L. A.; Nguyen, T. B.; Praske, E.; Schwantes, R. H.; Smarte, M. D.; St Clair, J. M.; Teng, A. P.; Zhang, X.; Seinfeld, J. H. Gas-phase reactions of isoprene and its major oxidation products. Chem. Rev. 2018, 118, 3337-3390.

(16) Keene, W. C.; Stutz, J.; Pszenny, A. A. P.; Maben, J. R.; Fischer, E. V.; Smith, A. M.; von Glasow, R.; Pechtl, S.; Sive, B. C.; Varner, R. $\mathrm{K}$. Inorganic chlorine and bromine in coastal New England air during summer. J. Geophys. Res.: Atmos. 2007, 112, D21202.

(17) Wang, X.; Deane, G. B.; Moore, K. A.; Ryder, O. S.; Stokes, M. D.; Beall, C. M.; Collins, D. B.; Santander, M. V.; Burrows, S. M.; Sultana, C. M.; Prather, K. A. The role of jet and film drops in controlling the mixing state of submicron sea spray aerosol particles. Proc. Natl. Acad. Sci. U.S.A. 2017, 114, 6978-6983.

(18) Quinn, P. K.; Collins, D. B.; Grassian, V. H.; Prather, K. A.; Bates, T. S. Chemistry and related properties of freshly emitted sea spray aerosol. Chem. Rev. 2015, 115, 4383-4399.
(19) Blanchard, D. C. Electrically Charged Drops From Bubbles In Sea Water And Their Meteorological Significance. J. Meteorol. 1958, $15,383$.

(20) Blanchard, D. C. The electrification of the atmosphere by particles from bubbles in the sea. Prog. Oceanogr. 1963, 1, 73-202.

(21) Blanchard, D. C. Sea-to-air Transport Of Surface Active Material. Science 1964, 146, 396.

(22) Blanchard, D. C. The Ejection of Drops from the Sea and Their Enrichment with Bacteria and Other Materials: A Review. Estuaries 1989, 12, 127.

(23) Duce, R. A.; Hoffman, E. J. Chemical fractionation at the air/ sea interface. Annu. Rev. Earth Planet. Sci. 1976, 4, 187-228.

(24) Chance, R.; Baker, A. R.; Carpenter, L.; Jickells, T. D. The distribution of iodide at the sea surface. Environ. Sci.: Processes Impacts 2014, 16, 1841-1859.

(25) Gilfedder, B. S.; Lai, S. C.; Petri, M.; Biester, H.; Hoffmann, T. Iodine speciation in rain, snow and aerosols. Atmos. Chem. Phys. 2008, $8,6069-6084$.

(26) Donaldson, D. J. Adsorption of atmospheric gases at the airwater interface. I. $\mathrm{NH}_{3}$. J. Phys. Chem. A 1999, 103, 62-70.

(27) Donaldson, D. J.; Vaida, V. The influence of organic films at the air-aqueous boundary on atmospheric processes. Chem. Rev. 2006, $106,1445-1461$.

(28) Valsaraj, K. T. Trace gas adsorption thermodynamics at the air-water interface: Implications in atmospheric chemistry. Pure Appl. Chem. 2009, 81, 1889-1901.

(29) Colussi, A.; Enami, S. Detecting intermediates and products of fast heterogeneous reactions on liquid surfaces via online mass spectrometry. Atmosphere 2019, 10, 47.

(30) Enami, S.; Vecitis, C. D.; Cheng, J.; Hoffmann, M. R.; Colussi, A. J. Electrospray mass spectrometric detection of products and shortlived intermediates in aqueous aerosol microdroplets exposed to a reactive gas. J. Phys. Chem. A 2007, 111, 13032-13037.

(31) Enami, S.; Vecitis, C. D.; Cheng, J.; Hoffmann, M. R.; Colussi, A. J. Global inorganic source of atmospheric bromine. J. Phys. Chem. A 2007, 111, 8749-8752.

(32) Enami, S.; Vecitis, C. D.; Cheng, J.; Hoffmann, M. R.; Colussi, A. J. Mass spectrometry of interfacial layers during fast aqueous aerosol/ozone gas reactions of atmospheric interest. Chem. Phys. Lett. 2008, 455, 316-320.

(33) Ingram, A. J.; Boeser, C. L.; Zare, R. N. Going beyond electrospray: mass spectrometric studies of chemical reactions in and on liquids. Chem. Sci. 2016, 7, 39-55.

(34) Lee, J. K.; Banerjee, S.; Nam, H. G.; Zare, R. N. Acceleration of reaction in charged microdroplets. Q. Rev. Biophys. 2015, 48, 437444.

(35) Mondal, S.; Acharya, S.; Biswas, R.; Bagchi, B.; Zare, R. N. Enhancement of reaction rate in small-sized droplets: A combined analytical and simulation study. J. Chem. Phys. 2018, 148, 244704.

(36) Jacob, D. J. The oxidizing power of the atmosphere. Handbook of Weather, Climate and Water; Wiley, 2003; pp 29-46.

(37) Liu, Q.; Schurter, L. M.; Muller, C. E.; Aloisio, S.; Francisco, J. S.; Margerum, D. W. Kinetics and mechanisms of aqueous ozone reactions with bromide, sulfite, hydrogen sulfite, iodide, and nitrite ions. Inorg. Chem. 2001, 40, 4436-4442.

(38) Sakamoto, Y.; Yabushita, A.; Kawasaki, M.; Enami, S. Direct emission of I2 molecule and IO radical from the heterogeneous reactions of gaseous ozone with aqueous potassium iodide solution. $J$. Phys. Chem. A 2009, 113, 7707-7713.

(39) Moreno, C. G.; Gálvez, O.; López-Arza Moreno, V.; EspildoraGarcía, E. M.; Baeza-Romero, M. T. A revisit of the interaction of gaseous ozone with aqueous iodide. Estimating the contributions of the surface and bulk reactions. Phys. Chem. Chem. Phys. 2018, 20, 27571-27584.

(40) Carpenter, L. J.; MacDonald, S. M.; Shaw, M. D.; Kumar, R.; Saunders, R. W.; Parthipan, R.; Wilson, J.; Plane, J. M. C. Atmospheric iodine levels influenced by sea surface emissions of inorganic iodine. Nat. Geosci. 2013, 6, 108. 
(41) Artiglia, L.; Edebeli, J.; Orlando, F.; Chen, S.; Lee, M.-T.; Arroyo, P. C.; Gilgen, A.; Bartels-Rausch, T.; Kleibert, A.; Vazdar, M. A surface-stabilized ozonide triggers bromide oxidation at the aqueous solution-vapour interface. Nat. Commun. 2017, 8, 700.

(42) Hayase, S.; Yabushita, A.; Kawasaki, M.; Enami, S.; Hoffmann, M. R.; Colussi, A. J. Heterogeneous reaction of gaseous ozone with aqueous iodide in the presence of aqueous organic species. J. Phys. Chem. A 2010, 114, 6016-6021.

(43) Atkinson, R.; Arey, J. Atmospheric chemistry of biogenic organic compounds. Acc. Chem. Res. 1998, 31, 574-583.

(44) Atkinson, R.; Winer, A. M.; Pitts, J. N., Jr. Rate constants for the gas phase reactions of $\mathrm{O}_{3}$ with the natural hydrocarbons isoprene and $\alpha$ - and $\beta$-pinene. Atmos. Environ. 1982, 16, 1017-1020.

(45) Lai, S. C.; Williams, J.; Arnold, S. R.; Atlas, E. L.; Gebhardt, S.; Hoffmann, $\mathrm{T}$. Iodine containing species in the remote marine boundary layer: A link to oceanic phytoplankton. Geophys. Res. Lett. 2011, 38, L20801.

(46) Lai, S. C.; Hoffmann, T.; Xie, Z. Q. Iodine speciation in marine aerosols along a 30,000 km round-trip cruise path from Shanghai, China to Prydz Bay, Antarctica. Geophys. Res. Lett. 2008, 35, L21803.

(47) Xu, S.; Xie, Z.; Li, B.; Liu, W.; Sun, L.; Kang, H.; Yang, H.; Zhang, P. Iodine speciation in marine aerosols along a $15000-\mathrm{km}$ round-trip cruise path from Shanghai, China, to the Arctic Ocean. Environ. Chem. 2010, 7, 406-412.

(48) Gilfedder, B. S.; Chance, R.; Dettmann, U.; Lai, S. C.; Baker, A. R. Determination of total and non-water soluble iodine in atmospheric aerosols by thermal extraction and spectrometric detection (TESI). Anal. Bioanal. Chem. 2010, 398, 519-526.

(49) Carpenter, L. J. Iodine in the marine boundary layer. Chem. Rev. 2003, 103, 4953-4962.

(50) Žic, V.; Truesdale, V. W.; Garnier, C.; Cukrov, N. The distribution of iodine in the Croatian marine lake Mir-The missing iodate. Estuarine, Coastal Shelf Sci. 2012, 115, 377-387.

(51) Truesdale, V. W.; Žic, V.; Garnier, C.; Cukrov, N. Circumstantial evidence in support of org-I as a component of the marine aerosol arising from a study of marine foams. Estuarine, Coastal Shelf Sci. 2012, 115, 388-398.

(52) Sipilä, M.; Sarnela, N.; Jokinen, T.; Henschel, H.; Junninen, H.; Kontkanen, J.; Richters, S.; Kangasluoma, J.; Franchin, A.; Peräkylä, O.; Rissanen, M. P.; Ehn, M.; Vehkamäki, H.; Kurten, T.; Berndt, T.; Petäjä, T.; Worsnop, D.; Ceburnis, D.; Kerminen, V.-M.; Kulmala, M.; O'Dowd, C. Molecular-scale evidence of aerosol particle formation via sequential addition of $\mathrm{HIO}_{3}$. Nature 2016, 537, 532.

(53) Enami, S.; Ishizuka, S.; Colussi, A. J. Chemical signatures of surface microheterogeneity on liquid mixtures. J. Chem. Phys. 2019, 150, 024702.

(54) Enami, S.; Hoffmann, M. R.; Colussi, A. J. Acidity enhances the formation of a persistent ozonide at aqueous ascorbate/ozone gas interfaces. Proc. Natl. Acad. Sci. U.S.A. 2008, 105, 7365-7369.

(55) Enami, S.; Mishra, H.; Hoffmann, M. R.; Colussi, A. J. Hofmeister effects in micromolar electrolyte solutions. J. Chem. Phys. 2012, 136, 154707.

(56) Hoigné, J.; Bader, H. Rate constants of reactions of ozone with organic and inorganic compounds in water-I: non-dissociating organic compounds. Water Res. 1983, 17, 173-183.

(57) Lin, X.; Ma, Q.; Yang, C.; Tang, X.; Zhao, W.; Hu, C.; Gu, X.; Fang, B.; Gai, Y.; Zhang, W. Kinetics and mechanisms of gas phase reactions of hexenols with ozone. RSC Adv. 2016, 6, 83573-83580.

(58) Sotelo, J. L.; Beltrán, F. J.; Benitez, F. J.; Beltrán-Heredia, J. Henry's law constant for the ozone-water system. Water Res. 1989, 23, $1239-1246$

(59) Qiu, J.; Ishizuka, S.; Tonokura, K.; Colussi, A. J.; Enami, S. Reactivity of Monoterpene Criegee Intermediates at Gas-Liquid Interfaces. J. Phys. Chem. A 2018, 122, 7910-7917.

(60) Enami, S.; Hoffmann, M. R.; Colussi, A. J.; Enami, S.; Hoffmann, M. R.; Colussi, A. J. Prompt Formation of Organic Acids in Pulse Ozonation of Terpenes on Aqueous Surfaces. J. Phys. Chem. Lett. 2010, 1, 2374-2379.
(61) Enami, S.; Colussi, A. J. Efficient scavenging of Criegee intermediates on water by surface-active cis-pinonic acid. Phys. Chem. Chem. Phys. 2017, 19, 17044-17051.

(62) Enami, S.; Colussi, A. J. Criegee Chemistry on Aqueous Organic Surfaces. J. Phys. Chem. Lett. 2017, 8, 1615-1623.

(63) Lee, J. K.; Samanta, D.; Nam, I.; Nam, H. G.; Zare, R. N. Spontaneous Reduction of Biomolecules on the Surface of Water Droplets. Biophys. J. 2018, 114, 542a.

(64) Brent, L. C.; Reiner, J. L.; Dickerson, R. R.; Sander, L. C. Method for Characterization of Low Molecular Weight Organic Acids in Atmospheric Aerosols Using Ion Chromatography Mass Spectrometry. Anal. Chem. 2014, 86, 7328-7336.

(65) Johnson, D.; Marston, G. The gas-phase ozonolysis of unsaturated volatile organic compounds in the troposphere. Chem. Soc. Rev. 2008, 37, 699-716.

(66) Hernando, M.; Schloss, I. R.; Almandoz, G. O.; Malanga, G.; Varela, D. E.; De Troch, M. Combined effects of temperature and salinity on fatty acid content and lipid damage in Antarctic phytoplankton. J. Exp. Mar. Biol. Ecol. 2018, 503, 120-128.

(67) Yodle, C.; Baker, A. R. Influence of collection substrate and extraction method on the speciation of soluble iodine in atmospheric aerosols. Atmos. Environ. 2019, 1, 100009.

(68) Boylan, P.; Helmig, D.; Oltmans, S. Ozone in the Atlantic Ocean marine boundary layer. Elem. Sci. Anth. 2015, 3, 000045.

(69) Moreda-Piñeiro, A.; Romarís-Hortas, V.; Bermejo-Barrera, P. A review on iodine speciation for environmental, biological and nutrition fields. J. Anal. At. Spectrom. 2011, 26, 2107-2152.

(70) Davidovits, P.; Kolb, C. E.; Williams, L. R.; Jayne, J. T.; Worsnop, D. R. Mass Accommodation and Chemical Reactions at Gas-Liquid Interfaces. Chem. Rev. 2006, 106, 1323-1354.

(71) Enami, S.; Hoffmann, M. R.; Colussi, A. J. Dry Deposition of Biogenic Terpenes via Cationic Oligomerization on Environmental Aqueous Surfaces. J. Phys. Chem. Lett. 2012, 3, 3102-3108.

(72) Chang, W.; Heikes, B. G.; Lee, M. Ozone deposition to the sea surface: chemical enhancement and wind speed dependence. Atmos. Environ. 2004, 38, 1053-1059.

(73) Dickerson, R. R.; Rhoads, K. P.; Carsey, T. P.; Oltmans, S. J.; Burrows, J. P.; Crutzen, P. J. Ozone in the remote marine boundary layer: A possible role for halogens. J. Geophys. Res.: Atmos. 1999, 104, 21385-21395.

(74) Read, K. A.; Mahajan, A. S.; Carpenter, L. J.; Evans, M. J.; Faria, B. V. E.; Heard, D. E.; Hopkins, J. R.; Lee, J. D.; Moller, S. J.; Lewis, A. C.; Mendes, L.; McQuaid, J. B.; Oetjen, H.; Saiz-Lopez, A.; Pilling, M. J.; Plane, J. M. C. Extensive halogen-mediated ozone destruction over the tropical Atlantic Ocean. Nature 2008, 453, 1232.

(75) Nissanka, I. D.; Park, H. J.; Freire, L. S.; Chamecki, M.; Reid, J. S.; Richter, D. H. Parameterized vertical concentration profiles for aerosols in the marine atmospheric boundary layer. J. Geophys. Res.: Atmos. 2018, 123, 9688-9702.

(76) Palmer, P. I.; Shaw, S. L. Quantifying global marine isoprene fluxes using MODIS chlorophyll observations. Geophys. Res. Lett. 2005, 32, L09805. 